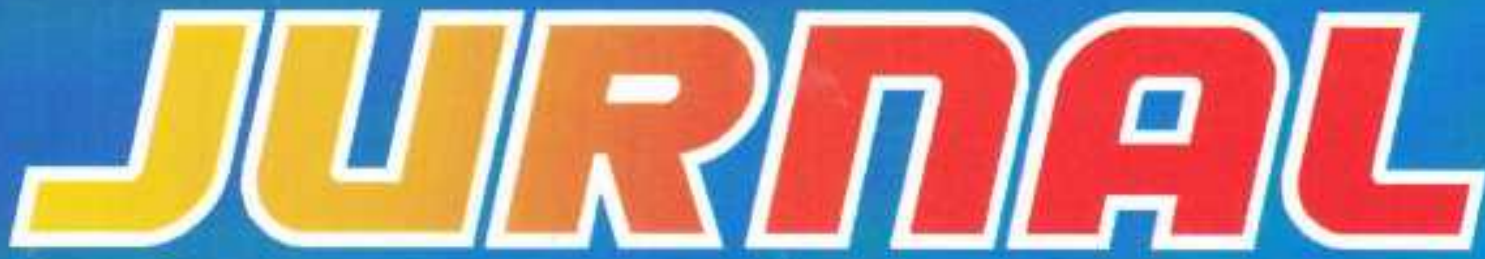

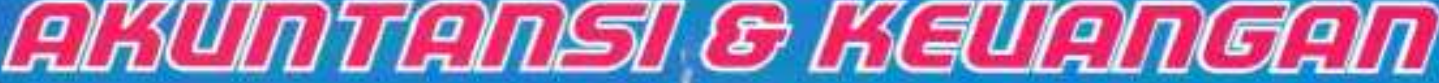

Volume 6, No. 1, Maret 2015

ISSN: $2087-2054$

Pengaruh Peran Acoount Representative Terhadap Tingkat Kepatuhan Wajib Pajak (Studi kasus pada KPP Pratama di Kota Bandar Lampung)

\section{Angrita Denziana \& Handi Sutanto}

Pengaruh Biaya Iklan Dan Biaya Penjualan Personal Terhadap Nilai Penjualan Pada PT Telekomunikasi Indonesia, Tbk.

\section{Chairul Anwar \& Rinna}

Relationship Executives Rewards With Financial Performance On Corporate Banking In Indonesia

\section{Haninun \& Putri Cagora Nisa}

Analisis Penerapan Metode Pengakuan Pendapatan Terhadap Laba Perusahaan Pada Pt. Coca Cola Distribusi Indonesia (Cabang Tanjung Karang)

\section{Herry Goenawan Soedarsa \& Surya Pandelima}

Pengaruh Tingkat Suku Bunga Simpanan Terhadap Jumlah Deposito Pada Pt. Bank Rakyat Indonesia (Persero) Tbk. Cabang Liwa

\section{Indrayenti \& Susanti}

Pengaruh Motivasi Terhadap Minat Mahasiswa Akuntansi Untuk Mengikuti Pendidikan Profesi Akuntansi (PPAK) Di Provinsi Lampung

\section{Rosmiaty Tarmizi \& Julia Restuti}

Pengaruh Kinerja Hutang Terhadap Nilai Perusahaan Pada Perusahaan Pertambangan Batubara Yang Terdaftar Di Bei Periode 2010-2013

\section{Khairudin \& Rico Tanto}

Pengaruh Profitabilitas, Ukuran Perusahaan, Debt To Equity Terhadap Ketepatan Waktu Penyampaian Laporan Keuangan (Studi Pada Perusahaan Asuransi Yang Terdaftar Di BEI)

\section{Riswan \& Tri Lestari Saputri}

Pengaruh Manajemen Laba Terhadap Kinerja Keuangan Pada Perusahaam Manufaktur Tahun 2011-2012

\section{Aminah \& Lidya Natasia Gunakan}




\section{Dewan Pembina}

Dr. Ir. M. Yusuf S. Barusman, M.B.A

Dr. Andala Rama Putra Barusman, S.E., M.A.Ec.

\section{Penanggung Jawab}

Dra. Rosmiaty Tarmizi, M.M.Akt. C.A

\section{Pimpinan Redaksi}

Dr. Angrita Denziana, S.E., M.M, Ak. C.A

\section{Sekretaris Redaksi}

Aminah, S.E., M.S.Ak

Khairudin, S.E., M.S.Ak

\section{Penyuting Ahli}

Prof. Dr. Jogiyanto Hartono, M.B.A. ( Universitas Gadjah Mada)

Tina Miniawati, S.E., M.B.A. (Universitas Trisakti)

Dr. Khomsiyah, S.E., M.M. (Universitas Trisakti)

Dr. Lindrianasari, S.E., M.Si.Akt. (Universitas Lampung)

Sujoko Efferin, Mcom (Hons), MA(Econ), Ph.D. (Universitas Surabaya)

\section{Penerbit}

Universitas Bandar Lampung

Fakultas Ekonomi dan Bisnis Program Studi Akuntansi

SENARAI-Jurnal Akuntansi \& Keuangan Terbit 2 kali setahun pada bulan Maret \&

September

Artikel yang dimuat berupa hasil riset Empiris dan telaah teoritis konsepsual yang kritis dalam kajian bidang akuntansi, auditing, perpajakan, dan keuangan.

\section{Alamat Redaksi}

Gedung G- Program Studi Akuntansi Fakultas Ekonomi dan Bisnis Universitas Bandar Lampung

Kampus A Jalan Z.A Pagar Alam No. 26 Labuan Ratu Bandar Lampung 35142

Telp: (0721) 701979, Fax: (0721) 701467, Email: Prodi.akuntansi@ubl.ac.id 


\section{JURNAL \\ AKUNTANSI \& KEUANGAN}

Volume 6, No. 1, Maret 2015

ISSN: 2087-2054

Pengaruh Peran Acoount Representative Terhadap Tingkat Kepatuhan Wajib Pajak

(Studi Kasus pada KPP Pratama di Kota Bandar Lampung)

Angrita Denziana \& Handi Sutanto

Pengaruh Biaya Iklan dan Biaya Penjualan Personal Terhadap Nilai Penjualan Pada PT

Telekomunikasi Indonesia, Tbk.

\section{Chairul Anwar \& Rinna}

Relationship Executives Rewards With Financial Performance On Corporate Banking In Indonesia

\section{Haninun \& Putri Cagora Nisa}

Analisis Penerapan Metode Pengakuan Pendapatan Terhadap Laba Perusahaan Pada PT. Coca Cola Distribusi Indonesia (Cabang Tanjung Karang)

Herry Goenawan Soedarsa \& Surya Pandelima

Pengaruh Tingkat Suku Bunga Simpanan Terhadap Jumlah Deposito Pada PT. Bank Rakyat Indonesia (Persero) Tbk. Cabang Liwa

Indrayenti \& Susanti

Pengaruh Motivasi Terhadap Minat Mahasiswa Akuntansi Untuk Mengikuti Pendidikan Profesi Akuntansi (PPAK) Di Provinsi Lampung

\section{Rosmiaty Tarmizi \& Julia Restuti}

Pengaruh Kinerja Hutang Terhadap Nilai Perusahaan Pada Perusahaan Pertambangan Batubara Yang Terdaftar Di BEI Periode 2010-2013

\section{Khairudin \& Rico Tanto}

Pengaruh Profitabilitas, Ukuran Perusahaan, Debt To Equity Terhadap Ketepatan Waktu Penyampaian Laporan Keuangan (Studi Pada Perusahaan Asuransi Yang Terdaftar Di BEI) Riswan \& Tri Lestari Saputri

Pengaruh Manajemen Laba Terhadap Kinerja Keuangan Pada Perusahaam Manufaktur Tahun 2011-2012

\section{Aminah \& Lidya Natasia Gunakan}




\section{JURNAL \\ AKUNTANSI \& KEUANGAN}

Volume 6, No. 1, Maret 2015

ISSN: 2087-2054

Daftar Isi

Halaman

$1-22$

Pengaruh Peran Acoount Representative Terhadap Tingkat Kepatuhan

Wajib Pajak (Studi kasus pada KPP Pratama di Kota Bandar Lampung)

Angrita Denziana \& Handi Sutanto

Pengaruh Biaya Iklan Dan Biaya Penjualan Personal Terhadap Nilai

Penjualan Pada PT Telekomunikasi Indonesia, Tbk.

Chairul Anwar \& Rinna

Relationship Executives Rewards With Financial Performance On

Corporate Banking In Indonesia

Haninun \& Putri Cagora Nisa

Analisis Penerapan Metode Pengakuan Pendapatan Terhadap Laba

Perusahaan Pada PT. Coca Cola Distribusi Indonesia (Cabang Tanjung

Karang)

Herry Goenawan Soedarsa \& Surya Pandelima

Pengaruh Tingkat Suku Bunga Simpanan Terhadap Jumlah Deposito Pada

PT. Bank Rakyat Indonesia (Persero) Tbk. Cabang Liwa

Indrayenti \& Susanti

Pengaruh Motivasi Terhadap Minat Mahasiswa Akuntansi Untuk

Mengikuti Pendidikan Profesi Akuntansi (PPAK) Di Provinsi Lampung

Rosmiaty Tarmizi \& Julia Restuti

Pengaruh Kinerja Hutang Terhadap Nilai Perusahaan Pada Perusahaan

Pertambangan Batubara Yang Terdaftar Di BEI Periode 2010-2013

\section{Khairudin \& Rico Tanto}

Pengaruh Profitabilitas, Ukuran Perusahaan, Debt To Equity Terhadap

Ketepatan Waktu Penyampaian Laporan Keuangan (Studi Pada Perusahaan Asuransi Yang Terdaftar Di BEI)

Riswan \& Tri Lestari Saputri

Pengaruh Manajemen Laba Terhadap Kinerja Keuangan Pada Perusahaam Manufaktur Tahun 2011-2012

Aminah \& Lidya Natasia Gunakan 


\section{JURNAL AKUNTANSI \& KEUANGAN}

Volume 6, No. 1, Maret 2015

ISSN: $2087-2054$

\section{Informasi Kebijakan dan Selingkung Berkala}

\section{Kebijakan editorial}

JURNAL Akuntansi \& Keuangan adalah sebuah berkala yang dipublikasikan oleh Universitas Bandar Lampung, yang bertujuan untuk menjadi wadah kreatifitas para akademisi, profesional, peneliti, dan mahasiswa di bidang Akuntansi dan Keuangan termasuk juga bidang Auditing, Sistem Informasi Akuntansi, Tata kelola Perusahaan, Perpajakan, Akuntansi Internasional, Akuntansi Managemen, Akuntansi Keperilakuaan, Pasar Modal dan lain sebagainya. Topik yang semakin meluas di bidang kajian riset Akuntansi diakomodir publikasinya di dalam berkala ini.

Paper yang akan dipublikasikan di dalam berkala JURNAL Akuntansi \& Keuangan harus ditulis di dalam bahasa Indonesia yang baik dan sesuai dengan EYD. Semua instrumen yang digunakan untuk memperoleh data penelitian harus dimasukkan di dalam lampiran paper penelitian, paling tidak, penulis bersedia memberikan klarifikasi atas instrumen yang digunakan saat ada permintaan dari peneliti lainnya.

\section{Sekretariat Editor Berkala}

Gedung F - Fakultas Ekonomi Universitas Bandar Lampung

Fakultas Ekonomi Program Studi Akuntansi

Kampus A Jalan Z.A. Pagar Alam No. 26 Labuhan Ratu Bandar Lampung 35142

$$
\text { Telp.: (0721) 701979, Fax.: (0721) 701467, Email: }
$$

\section{Petunjuk penulisan}

Artikel yang dikirim ke JURNAL Akuntansi \& Keuangan harus mengikuti petunjuk seperti berikut:

1. Naskah merupakan naskah asli yang belum pernah diterbitkan atau sedang dilakukan penilaian pada berkala lain. Naskah ditulis dalam bahasa Indonesia dengan jarak 1 spasi, sepanjang 20-30 halaman kertas A4 dengan tipe huruf Times New Roman.. Naskah dikirim atau diserahkan ke sekretariat JURNAL Akuntansi \& Keuangan rangkap satu disertai disket berikut dengan biodata penulis dan alamat lengkap (kantor dan rumah) pada lembaran yang terpisah dari halaman pertama artikel.

2. Judul naskah dapat ditulis dengan menggambarkan isi pokok tulisan, dan atau ditulis secara ringkas, jelas, dan menarik. 
3. Nama Penulis disertai catatan kaki tentang profesi dan lembaga tempat penulis bekerja dalam naskah yang telah diterima untuk diterbutkan.

4. Abstrak ketik satu spasi, tidak lebih dari 250 kata dalam bahasa Inggris. Abstrak memuat tujuan penelitian, isu, permasalahan, sampel dan metode penelitian, serta hasil dan simpulan (jika memungkinan).

5. Pendahuluan beriksikan uraian tentang latar belakang masalah, ruang lingkup penelitian, dan telaah pustaka yang terkait dengan permasalahan yang dikaji, serta rumusan hipotesis (jika ada). Uraian pendahuluan maksimum $10 \%$ total halaman.

6. Untuk penelitian kuantitatif,

a. Telaah Literatur dan Pengembangan Hipotesis memuat paling tidak satu buah teori yang menjadi dasar pemikiran penelitian. Hipotesis dikembangkan menggunakan asumsi dasar teori dan hasil penelitian sebelumnya. Telah literatur maksimum $40 \%$ total halaman.

b. Metodologi Penelitian meliputi uraian yang rinci tentang bahan yang digunakan, metoda yang dipilih, teknik, dan cakupan penelitian. Uraian bahan dan metoda maksimum $20 \%$ total halaman.

7. Untuk penelitian kualitatif menyesuaikan dengan metodologi kualitatif.

8. Hasil dan Pembahasan merupakan uraian obyektif dari-hasil penelitian dan pembahasan dilakukan untuk memperkaya makna hasil penelitian. Uraian hasil dan pembahasan minimum $25 \%$ total halaman.

9. Simpulan yang merupakan rumusan dari hasil-hasil penelitian. Harus ada sajian dalam satu kalimat inti yang menjadi simpulan utama. Simpulan maksimum 10\% dari keseluruhan lembar artikel.

10. Referensi (Daftar Pustaka) ditulis berurutan berdasarkan alphabetical, disusun menggunakan suku kata terakhir dari nama penulisnya, atau institusi jika dikeluarkan oleh organisasi.

a. Buku: nama penulis, tahun penerbitan, judul lengkap buku, penyunting (jika ada), nama penerbit, dan kota penerbitan.

b. Artikel dalam buku: nama penulis, tahun penerbitan, judul artikel/tulisan, judul buku, nama penyunting, kota penerbitan, nama penerbit, dan halaman.

c. Terbitan berkala: nama penulis, tahun penerbitan, judul tulisan, judul terbitan (bila disingkat, sebaiknya menggunakan singkatan yang baku), volume, nomor, dan halaman.

d. Artikel dalam internet: nama penulis, judul, dan situsnya.

e. Tabel diberi nomor dan judul dilengkapi dengan sumber data yang ditulis dibawah badan tabel, diikuti tempat dan waktu pengambilan data.

f. Ilustrasi dapat berupa gambar, grafik, diagram, peta, dan foto diberi nomor dan judul.

11. Setiap referensi yang digunakan di dalam naskah artikel menggunakan petunjuk yang dirujuk pada The Indonesian Journal of Accounting Research, sebagai berikut:

A. Kutipan dalam tubuh naskah paper harus disesuaikan dengan contoh berikut:

I. Satu sumber kutipan dengan satu penulis (Brownell, 1981).

II. Satu sumber kutipan dengan dua penulis (Frucot dan Shearon, 1991).

III. Satu sumber kutipan dengan lebih dari satu penulis (Hotstede et al., 1990).

IV. Dua sumber kutipan dengan penulis yang berbeda (Dunk, 1990; Mia, 1988).

V. Dua sumber kutipan dengan satu penulis (Brownell, 1981, 1983).

VI. Dua sumber kutipan dengan satu penulis diterbitkan pada tahun yang sama (Brownell, 1982a, 1982b). 
VII. Sumber kutipan dari lembaga harus dinyatakan dengan menggunakan akronim institusi (FASB, 1994)

B. Setiap artikel harus menulis referensi menggunakan panduan berikut:

I. Referensi harus tercantum dalam urutan abjad dari nama belakang penulis atau nama lembaga.

II. Referensi harus dinyatakan dengan urutan sebagai berikut: penulis (s) nama, tahun publikasi, judul kertas atau buku teks, nama jurnal atau penerbit dan nomor halaman. Contoh:

a) Amerika Akuntansi Association, Komite Konsep dan Standar Laporan Keuangan Eksternal. 1977. Pernyataan tentang Teori Akuntansi dan Teori Penerimaan. Sarasota, FL: AAA.

b) Demski, J. S., dan D. E. M. Sappington. 1989. Struktur hirarkis dan akuntansi pertanggungjawaban, Jurnal Akuntansi Penelitian 27 (Spring): 40-58.

c) Dye, R. B., dan R. Magee. 1989. Biaya Kontijensi untuk perusahaan audit. Kertas kerja, Northwestern University, Evansto, IL.

d) Indriantoro, N. 1993. Pengaruh Penganggaran Partisipatif Terhadap Prestasi Kerja dan Kepuasan Kerja dengan Locus of Control dan Dimensi Budaya sebagai Moderating Variabel. Ph.D. Disertasi. University of Kentucky, Lexington.

e) Naim, A. 1997. Analisis Penggunaan Akuntansi Biaya Produk Dalam Keputusan Harga oligopolistik. Jurnal Ekonomi Dan Bisnis Indonesia 12 (3): 43-50.

f) Porcano, T. M. 1984a. Keadilan distributif dan Kebijakan Pajak. Akuntansi Ulasan 59 (4): 619-636.

g) -------. 1984b. Pengaruh Persepsi Kebijakan Pajak Niat Investasi Perusahaan. The Journal of American Association Perpajakan 6 (Fall): 719.

h) Pyndyk, R. S. dan D. L. Rubinfield. 1987. Model ekonometrik \& Forecasts Ekonomi, 3rd ed. NY: McGraw-Hill Publishing, Inc.

12. Author(s) harus melampirkan CV, alamat email, alamat korespondensi dan pernyataan yang menyatakan pasal tersebut tidak sedang disampaikan kepada atau diterbitkan oleh jurnal lain dalam email tersebut dan /atau pos. 


\title{
RELATIONSHIP EXECUTIVES REWARDS WITH FINANCIAL PERFORMANCE ON CORPORATE BANKING IN INDONESIA
}

\author{
Haninun \\ Putri Cagora Nisa \\ (Universitas Bandar Lampung) \\ email:haninun@ubl.ac.id \\ email: putri_cagora@yahoo.com
}

\begin{abstract}
The purpose of this research is to know the relationship of Executive rewards and financial performance on corporate banking in Indonesia. This research using a sample of as many as 14028 banking company which is listed on the Indonesia stock exchange, whereas the observed financial reports for the past five consecutive years 2007 to 2011. Method of data collection was done manually inputted into the tabulated using excel. While the analysis used to determine the relationship of free variables (X) Executive Award (reward) and variable (Y), namely the financial performance is a non-parametric statistical analysis that tests rank correlation.

The result of this research shows that by using the level of significance of 0.05 as a twosided test then $2.5 \%$ and $n=140$ obtained a table $t=1,977$. Whereas $t$ calculate for debt to equity as seen from the output though the data is 1,3001 ( $t$ count $<t$ table) then based on this $t$-test concluded the Executive reward no relationship with financial performance. Likewise testing to return on investment and return on equity, show $t$ 5,7884 and 6,63034 of count ( $t$ count $>\quad t$ table) then concluded the Executive reward is a relationship with the financial performance of the banking companies listed on the Indonesia stock exchange.
\end{abstract}

Keywords: Eksecutive rewards, Debt to equity, ROI, and ROE

\section{Latar Belakang}

Salah satu faktor yang secara umum berdampak positif terhadap kinerja adalah reward (kompensasi). Untuk menjamin tercapainya keselarasan tujuan, pimpinan organisasi bisa memberikan perhatian dengan memberikan reward (kompensasi), karena reward (kompensasi) merupakan bagian dari hubungan timbal balik antara organisasi dengan sumber daya manusia. Reward (Kompensasi) menurut Hasibuan (2002: 117) adalah semua pendapatan yang berbentuk uang, barang langsung atau tidak langsung yang diterima karyawan sebagai imbalan atas jasa yang diberikan kepada perusahaan.

Dengan demikian, melalui reward (kompensasi) yang layak diharapkan terjadi peningkatan motivasi kerja karyawan dan berdampak pula pada peningkatan kinerja perusahaan. Kinerja perusahaan dapat dilihat melalui berbagai macam variabel atau indikator. Variabel atau indikator yang dijadikan dasar penilaian adalah laporan keuangan perusahaan yang bersangkutan. Apabila kinerja sebuah perusahaan publik meningkat, nilai keusahaannya 
akan semakin tinggi. Menurut Ikatan Akuntan Indonesia (IAI, 2010), kinerja perusahaan dapat diukur dengan menganalisa dan mengevaluasi laporan keuangan.

Informasi posisi dan kinerja keuangan dimasa lalu seringkali digunakan sebagai dasar untuk memprediksi posisi keuangan dan kinerja dimasa depan dan hal-hal lain yang langsung menarik perhatian pemakai seperti pembayaran deviden, upah, pergerakan harga sekuritas dan kemampuan perusahaan untuk memenuhi komitmennya ketika jatuh tempo. Kinerja merupakan hal penting yang harus dicapai oleh setiap perusahaan dimanapun, karena kinerja merupakan cerminan dari kemampuan perusahaan dalam mengelola dan mengalokasikan sumber dayanya.

\section{Telaah Literature dan Pengembangan Hipotesis}

\subsection{Teori yang mendasari}

\section{Sistem Penghargaan (Reward System)}

a. Defenisi Reward System

Reward dapat menarik perhatian karyawan dan memberi informasi atau mengingatkan mereka akan pentingnya sesuatu yang diberi reward dibandingkan dengan yang lain, reward juga meningkatkan motivasi karyawan terhadap ukuran kinerja, sehingga membantu karyawan bagaimana mereka mengalokasikan waktu dan usaha mereka. Reward berbasis kinerja mendorong karyawan mengubah kecenderungan mereka dari semangat untuk memenuhi kepentingan diri sendiri ke semangat untuk memenuhi tujuan organisasi. Reward berbasis kinerja memberi dua manfaat yakni memberi informasi dan memberikan motivasi (Mulyadi dan Johny, 2001).

b. Tujuan Reward System

Pada dasarnya tujuan reward system dapat dipandang dari tujuan utama secara umum dan tujuan perusahaan. Tujuan utama dari sistem penghargaan ini adalah memberikan tanggung jawab dan dorongan kepada karyawan dalam rangka meningkatkan kualitas dan kuantitas hasil kerjanya. Sedangkan tujuan perusahaan yang memberikan sistem penghargaan ini adalah sebagai strategi untuk meningkatkan produktifitas dan efisiensi perusahaan dalam menghadapi persaingan yang ketat.

c. Tantangan dalam Menerapkan Reward System

Menurut Rivai (2009), tantangan yang dihadapi organisasi dalam menerapkan reward system (sistem kompensasi) adalah: 
1) Perilaku yang tidak etis. Karena ada tekanan untuk berprestasi, insentif dapat mendorong karyawan untuk berbohong, menutup-nutupi informasi negatif, menjatuhkan rekan sendiri hanya agar telihat lebih baik.

2) Efek negatif dari semangat bekerjasama. Karyawan dapat menahan informasi bilamana mereka merasa bahwa apabila informasi tersebut disampaikan kepada rekannya, hal tersebut akan membuat rekan kerjanya berprestasi.

3) Kesulitan dalam penilaian kinerja. Pada level karyawan, atasan yang menilai harus berusaha memilah kinerja individu dan kontribusi kelompok dan menghindari penilaian berdasarkan bias personalitas (misalnya menilai terlalu lunak atau terlalu keras).

4) Ketidakpuasan kerja. Sistem kompensasi dapat meningkatkan produktivitas namun menurunkan tingkat kepuasan kerja. Semakin pembayaran insentif dikaitkan dengan kinerja, semakin banyak unit/kelompok yang tidak kompak dan semakin karyawan tidak bahagia. Hal tersebut terjadi karena masing-masing kelompok menonjolkan diri dan menjatuhkan kelompok kerja lainnya.

5) Potensi penurunan dorongan intrinsik. Reward system dapat mendorong karyawan untuk melakukan apa saja untuk mendapatkan insentif uang dan dalam prosesnya merusak bakat dan kreatifitasnya, sehingga karyawan yang tadinya bekerja dan membantu perusahaan tanpa terkait uang, akan menolak melakukan pekerjaan bila tidak ada imbalan uang.

d. Pengaruh Reward System (Insentif) Terhadap Kinerja

Menurut Sarwoto (2010), dalam bukunya Dasar-dasar Organisasi dan Manajemen mengatakan insentif sebagai suatu sarana motivasi dapat diberi batasan perangsang ataupun pendorong yang diberikan dengan sengaja kepada para pekerja agar dalam diri mereka timbul semangat yang lebih besar untuk berprestasi bagi organisasi.

\subsection{Pengertian dan Tujuan Laporan Keuangan}

\section{Pengertian Laporan Keuangan}

Ikatan Akuntan Indonesia (IAI, 2004) menguraikan pengertian dari laporan keuangan sebagai bagian dari proses pelaporan keuangan yang dilaporkan secara lengkap. Laporan keuangan biasanya berisi neraca, laporan laba rugi, laporan perubahan ekuitas, laporan perubahan posisi keuangan serta catatan-catatan atau laporan-laporan dan material penting lainnya yang merupakan bagian integral dari sebuah pelaporan keuangan. 


\section{Tujuan Laporan Keuangan}

Secara umum laporan keuangan bertujuan untuk memberikan informasi keuangan suatu perusahaan, baik pada saat tertentu maupun pada periode tertentu (Munawir, 2010). Laporan keuangan juga dapat dijadikan sebagai alat pertanggungjawaban oleh pihak yang bersangkutan.

\subsection{Kinerja Keuangan}

\section{Pengertian Kinerja Keuangan}

Menurut Fahmi (2011: 2) mengemukakan bahwa: Kinerja Keuangan adalah suatu analisis yang dilakukan untuk melihat sejauh mana suatu perusahaan telah melaksanakan dengan menggunakan secara baik dan benar sumberdaya finansial yang dimiliki. Sedangkan menurut Husnan dan Padjiastuti (2004: 200), seorang analis keuangan memerlukan ukuran tertentu, yang paling sering digunakan adalah rasio atau indeks yang menunjukkan hubungan antara data keuangan.

Menurut Munawir (2010: 30), kinerja keuangan perusahaan merupakan satu diantara dasar penilaian mengenai kondisi keuangan perusahaan yang dilakukan berdasarkan analisa terhadap rasio keuangan perusahaan.

\section{Analisis Rasio Keuangan}

Afriyeni (2008) menyatakan bahwa alat analisis laporan keuangan yang paling populer digunakan untuk mengetahui kondisi keuangan dan kinerja keuangan perusahaan adalah analisis rasio keuangan. Djarwanto (2001), mengungkapkan bahwa yang dimaksud dengan angka rasio dalam analisis laporan keuangan adalah: "Suatu angka yang menunjukkan hubungan antara suatu unsur dengan unsur lainnya dalam laporan keuangan. Hubungan antara unsur-unsur laporan keuangan tersebut dinyatakan dalam bentuk matematis yang sederhana". Bambang (2001) menambahkan: "Rasio hanyalah alat yang dinyatakan dalam arithmetical term yang dapat digunakan untuk menjelaskan hubungan antara dua macam data financial". Menurut Purba dan Sucipto (2009), jenis-jenis rasio keuangan yang biasa digunakan dalam analisis laporan keuangan antara lain:

\section{Rasio Likuiditas (liquidity ratio)}

Rasio likuiditas atau sering juga disebut dengan nama rasio modal kerja merupakan rasio yang digunakan untuk mengukur seberapa likuidnya suatu perusahaan. Caranya adalah dengan membandingkan seluruh komponen yang ada di aktiva lancar dengan komponen di 
pasiva lancar (utang jangka pendek). Rasio ini juga menunjukkan kemampuan perusahaan untuk membayar utang-utang (kewajiban) jangka pendeknya yang jatuh tempo.

Rasio likuiditas antara lain:

a) Rasio lancar (current ratio)

Rasio ini menunjukkan sejauh mana aktiva lancar menutupi kewajiban-kewajiban lancar. Semakin besar perbandingan aktiva lancar dengan utang lancar semakin tinggi kemampuan perusahaan menutupi kewajiban jangka pendeknya.

b) Rasio cepat (quick ratio atau acid test ratio)

Rasio ini menunjukkan kemampuan aktiva lancar yang paling likuid mampu menutupi utang lancar. Semakin besar rasio ini semakin baik. Rasio ini disebut juga Acid Test Rasio.

\section{Rasio Solvabilitas (leverage ratio)}

Rasio solvabilitas merupakan rasio yang digunakan untuk mengukur sejauh mana aktiva perusahaan dibiayai dengan utang. Seperti diketahui dalam mendanai usahanya, perusahaan memiliki beberapa sumber dana. Sumber-sumber dana yang dapat diperoleh adalah dari Rasio leverage antara lain:

a) Debt to asset ratio (debt ratio)

Debt ratio merupakan rasio yang digunakan untuk mengukur perbandingan antara total utang dengan total aktiva. Dengan kata lain seberapa besar aktiva perusahaan dibiayai oleh utang atau seberapa besar utang perusahaan berpengaruh terhadap pengelolaan aktiva dan biasanya dinyatakan dalam persentase.

b) Debt to equity ratio

Debt to equity ratio merupakan rasio yang digunakan untuk mengetahui perbandingan antara total utang dengan modal sendiri. Rasio ini berguna untuk mengetahui seberapa besar aktiva perusahaan dibiayai dari utang. Dengan kata lain rasio ini untuk mengetahui setiap rupiah modal sendiri yang dijadikan untuk jaminan utang dan biasanya rasio ini dinyatakan dalam persentase. Bagi bank semakin besar rasio ini akan semakin tidak menguntungkan, karena semakin besar resiko yang ditanggung atas kegagalan yang mungkin terjadi di perusahaan, namun bagi perusahaan justru semakin besar rasio akan semakin baik. 
c) Rasio kecukupan modal (Capital Adequacy Ratio - CAR)

Rasio ini menunjukkan kecukupan modal untuk menilai keamanan dan kesehatan bank dari sisi modal pemiliknya, yakni sejauh mana modal pemilik saham dapat menutupi aktiva berisiko.

\section{Rasio Aktivitas (activity ratio)}

Rasio aktivitas merupakan rasio yang digunakan untuk mengukur tingkat efisiensi pemanfaatan sumber daya perusahaan (penjualan, persediaan, penagihan piutang, dan lainnya). Atau rasio untuk menilai kemampuan perusahaan dalam melaksanakan aktifitas sehari-hari. Dari hasil pengukuran dengan rasio ini akan terlihat apakah perusahaan lebih efisien atau sebaliknya dalam mengelola aset yang dimilikinya. Rasio aktivitas terdiri-dari:

a) Perputaran piutang (receivable turnover)

Merupakan rasio yang digunakan untuk mengukur berapa lama penagihan piutang selama satu periode. Atau berapa kali dana yang ditanam dalam piutang ini berputar dalam satu periode. Semakin tinggi rasio menunjukkan bahwa modal kerja yang ditanamkan dalam piutang semakin rendah (bandingkan dengan tahun sebelumnya) dan tentunya kondisi ini bagi perusahaan semakin baik.

b) Perputaran aset (asset turnover)

Rasio ini menunjukkan efektifitas penggunaan seluruh harta perusahaan dalam menghasilkan penjualan atau menggambarkan berapa rupiah penjualan bersih yang dapat dihasilkan oleh setiap rupiah yang diinvestasikan dalam bentuk harta perusahaan. Kalau perputarannya lambat, ini menunjukkan bahwa aktiva yang dimiliki terlalu besar dibandingkan dengan kemampuan untuk menjual.

\section{Rasio Profitabilitas (profitability ratio)}

Rasio profitabilitas menggambarkan kemampuan perusahaan mendapatkan laba melalui semua kemampuan dan sumber yang ada seperti kegiatan penjualan, kas, modal, jumlah karyawan, dan sebagainya. Rasio profitabilitas antara lain:

a) Margin laba (profit margin)

Rasio ini diukur antara profit margin dengan penjualan dan diukur dalam persentase. Rasio ini dirumuskan:

b) Return On Investment (ROI) 
ROI merupakan rasio yang menunjukkan hasil (return) atas jumlah aktiva yang digunakan dalam perusahaan atau suatu ukuran tentang efisiensi manajemen. Rasio ini menunjukkan hasil dari seluruh aktiva yang dikendalikannya dengan mengabaikan sumber pendanaan dan biasanya rasio ini diukur dengan persentase. Rasio ini menunjukkan produktifitas dari seluruh dana perusahaan baik modal pinjaman maupun modal sendiri. Semakin kecil (rendah) rasio ini semakin tidak baik, demikian pula sebaliknya. Artinya rasio ini digunakan untuk mengukur efektifitas dari keseluruhan operasi perusahaan.

c) Return On Equity (ROE)

Rasio ini menunjukkan berapa persen laba bersih bila diukur dari modal pemilik. Semakin besar rasio ini semakin bagus.

d) Return On Asset (ROA)

Rasio ini menggambarkan perputaran aktiva. Semakin besar rasio ini semakin baik. Hal ini berarti bahwa aktiva dapat lebih cepat berputar dan meraih laba.

\subsection{Penelitian Terdahulu}

Nourayi and Mints. 2008, dengan judul Tenure, firm's performance, and CEO's compensation, hasil penelitian menemukan bahwa: kompensasi yang diberikan kepada CEO yang bekerja selama 3 tahun berpengaruh terhadap kinerja perusahaan, namun tidak berpengaruh signifikan bagi mereka dengan 15 tahun atau lebih sebagai CEO perusahaan.

a. Harvie et al. 2000, dengan judul Employees High-Performance Work Systems: Testing inside the Black Box, hasil penelitian menemukan bahwa melalui insentif orang akan termotivasi untuk bekerja dengan baik dan memberikan kinerja yang meningkat atau baik bagi perusahaan.

b. Angih Wanabkti P. 2011, dengan judul: Pengaruh pelatihan, penerapan SOP, Reward system, Lingkungan kerja dan peralatan terhadap produktivitas teknisi, dengan salah satu kesimpulan Dalam penelitian ini RS (Reward System) ternyata berpengaruh negatif terhadap Produktivitas Teknisi ditunjukkan dengan koefisien parameter sebesar -0.404 dan signifikan pada 5\% karena menunjukkan nilai T statistic sebesar 5,439 (> 1,96). Hal ini berarti reward system yang dijalankan di bengkel Urip PT. Hadji Kalla Toyota Makasar belum dapat memberikan pengaruh positif terhadap produktivitas teknisi.

c. Rian Angelina. 2012, dengan judul Effect of total quality management, reward system and organization commitment to managerial performance in hospital in Pekanbaru. 
Hasil penelitian hipotesis kedua menjelaskan bahwa variabel sistem reward berpengaruh terhadap kinerja manajerial.

\subsection{Hipotesis}

Adapun hipotesis yang diajukan pada penelitian ini adalah:

a. Ho: Tidak terdapat hubungan penghargaan eksekutif (reward) dengan kinerja keuangan perusahaan perbankan di Indonesia.

b. Ha: Terdapat hubungan penghargaan eksekutif (reward) dengan kinerja keuangan perusahaan perbankan di Indonesia.

\section{Metodologi Penelitian}

\subsection{Pemilihan Sampel}

Pada penelitian ini yang dijadikan sampel penelitian adalah 28 perusahaan perbankan dan laporan keuangan yang diamati selama lima tahun yaitu tahun 2007 hingga 2011. Adapun pemilihan sampel dengan purposive sampling dan kriteria sampel yang digunakan:

a. Laporan keuangan semua perusahaan perbankan yang beroperasi secara aktif selama tahun 2007 hingga 2011.

b. Perusahaan perbankan yang menyajikan laporan keuangan secara lengkap yang terdaftar di Bursa Efek Indonesia pada periode 2007 hingga 2011.

c. Perusahaan perbankan yang beroperasi secara continue atau terus-menerus selama periode penelitian.

d. Penulis menjadikan sektor perbankan sebagai objek penelitian karena dalam kondisi perekonomian yang sedang berkembang, sektor perbankan memiliki potensi dan peluang yang besar peranannya sebagai sumber pembiayaan bagi masyarakat dan sektor usaha.

\subsection{Data}

Data penelitian yang digunakan dalam studi ini adalah data sekunder yang diperoleh dari laporan keuangan perbankan di Indonesia. Data yang dimaksud adalah nilai remunerasi yang ada didalam masing-masing annual report perusahaan perbankan yang terdaftar di Bursa Efek Indonesia tahun 2007-2011. 


\subsection{Model Penelitian dan Pengujian Statistika}

Analisis Kuantitatif dilakukan dengan menggunakan variabel statistik guna mengetahui hubungan reward dengan kinerja keuangan dengan rumusan Korelasi Product Moment (Arikunto, 2008), yaitu :

$$
\mathrm{R}_{\mathrm{xy}}=\frac{\mathrm{N} \sum \mathrm{xy}-\left(\sum \mathrm{xy}\right)\left(\sum \mathrm{y}\right)}{\sqrt{ }\left(\mathrm{N} \sum \mathrm{x}^{2}-\left(\sum \mathrm{xy}\right)^{2}\right)\left(\mathrm{N} \sum \mathrm{y}^{2}-\left(\sum \mathrm{y}\right)^{2}\right)}
$$

Keterangan :

Rxy $=$ Nilai Korelasi Variabel X dan Y

$\sum \mathrm{x}=\operatorname{Reward}(\mathrm{X})$

$\sum \mathrm{y}=$ Kinerja keuangan

$\mathrm{N}$ = Jumlah Sampel, sebanyak 140 0bjek (28 perusahaan $\mathrm{x} 5$ tahun).

\subsection{Definisi Operasional Variabel Penelitian}

a. Reward (penghargaan)

Reward (penghargaan) merupakan jumlah remunerasi yaitu tunjangan; imbalan dalam; tunjangan bagi; upah yang diberikan perusahaan kepada anggota direksi. Pengukurannya menggunakan skala nominal.

b. Kinerja Keuangan

Kinerja keuangan pada penelitian ini diukur menggunakan indikator berupa debt to equity, return on investment, return on equity.

\section{Hasil dan Pembahasan}

\subsection{Data Penelitian}

Berdasarkan data sampel yang terdiri dari 28 bank dengan data selama lima tahun yaitu dari tahun 2007 hingga 2011, sehingga diperoleh sebanyak 140 data atau amatan. Dari seratus empat puluh data tersebut dilakukan olah data secara statistik deskriptif dan dapat dilihat sebagai berikut: 
Tabel 1.

Descriptive Statistics

\begin{tabular}{|l|l|r|r|r|r|}
\hline & $\mathrm{N}$ & Minimum & Maximum & \multicolumn{1}{|c|}{ Mean } & Std. Deviation \\
\hline Debt to equity & 140 & $-31,53$ & 16,859 & 8,889 & 4,658 \\
ROI & 140 & $-1,3035$ & 0,0353 & 0,0011 & 0,112 \\
ROE & 140 & $-0,3631$ & 4,7421 & 0,1622 & 0,467 \\
Reward & 140 & 898.572 .526 & 183.757 .000 .00 & 28.800 .000 .0 & 30.970 .000 .00 \\
& & & 0 & 00 & 0 \\
Valid N (listwise) & 140 & & & & \\
\hline
\end{tabular}

Dari tabel diatas diperoleh gambaran tentang data yang dihimpun yaitu; untuk debt to equity nilai maksimum adalah 16,859 yaitu Bank Artha Graha International pada tahun 2007 dan nilai minimum adalah -31,53 yaitu Bank Pundi Indonesia pada tahun 2009, sedangkan rata-rata adalah 8,889 . Untuk return on investment nilai tertinggi adalah 0.0353 yaitu Bank Mutiara tahun 2009 dan nilai terendah adalah -1,3035 yaitu Bank Mutiara tahun 2008 sedangkan rata-rata 0,001 . Untuk return on equity nilai tertinggi adalah 4,7421 yaitu Bank Mutiara tahun 2008, dan nilai terendah adalah -0,3631 yaitu Bank Pundi Indonesia tahun 2008 sedangkan rata-rata 0,1622. Selanjutnya angka reward diketahui angka tertinggi sebesar Rp.183.757.000.000,- yaitu Bank Mandiri tahun 2011, dan angka terendah adalah Rp. 898.572.526,-, yaitu Bank Pundi Indonesia tahun 2009 sedangkan rata-rata sebesar Rp. 28.800.000.000.

\subsection{Uji Normalitas}

Uji normalitas digunakan untuk mengetahui apakah populasi data berdisınousi normal atau tidak. Dalam pembahasan ini akan digunakan uji Lilliefor dengan melihat nilai pada Kolmogorov-Smirmov. Data dinyatakan berdistribusi normal jika signifikansi lebih besar dari 0,05 (Prayitno, 2010: 71). Hasil pengujian normalitas dapat dilihat pada tabel berikut:

Tabel 2

Tests of Normality

\begin{tabular}{|l|r|r|r|r|r|r|}
\hline \multirow{2}{*}{} & \multicolumn{3}{|c|}{ Kolmogorov-Smirnov $^{\text {a }}$} & \multicolumn{3}{|c|}{ Shapiro-Wilk } \\
\cline { 2 - 7 } & Statistic & \multicolumn{1}{c|}{ Df } & \multicolumn{1}{c|}{ Sig. } & Statistic & \multicolumn{1}{c|}{ Df } & \multicolumn{1}{c|}{ Sig. } \\
\hline Debt to & .157 & 140 & .000 & .672 & 140 & .000 \\
equity & & & & & & \\
ROI & .244 & 140 & .000 & .847 & 140 & .000 \\
ROE & .320 & 140 & .000 & .795 & 140 & .000 \\
Reward & .184 & 140 & .000 & .814 & 140 & .000 \\
\hline
\end{tabular}

a. Lilliefors Significance Correction 
Dari output di atas dapat dilihat pada kolom Kolmogorov -Smirmov dan dapat diketahui bahwa nilai signifikansi untuk semua indikator variabel tidak ada yang lebih besar dari 0,05 , maka dapat disimpulkan bahwa populasi tidak berdistribusi normal. Karena data variabel tidak berdistribusi normal, maka pada penelitian ini dilakukan uji rank korelasi (Susetyo, 2010: 227)

\subsection{Pengujian Hipotesis, Hasil dan Diskusi}

Menurut Susetyo (2010: 227) untuk pengujian dengan metode statistik parametrik diperlukan beberapa persyaratan yang salah satunya adalah data variabel harus berdistribusi normal. Berdasarkan hasil uji normalitas pada penelitian ini data tidak berdistribusi normal, sehingga penulis melakukan pengujian statistik non parametrik yang dalam hal ini adalah uji rank korelasi. Berdasarkan hasil perhitungan terhadap variabel X (reward) dan variabel Y (kinerja keuangan dengan indikator debt to equity, return on investment, dan return on equity) adalah sebagai berikut:

a. Koefisien korelasi reward dengan debt to equity:

$$
\mathrm{R}_{\mathrm{xy} 1}=1-\frac{6 \mathrm{x} 406.550}{140\left(140^{2}-1\right)}=0,110997
$$

b. Koefisien korelasi reward dengan return on investment:

$$
\mathrm{R}_{\mathrm{xy} 2}=1-\frac{6 \mathrm{x} 255.154}{140\left(140^{2}-1\right)}=0,442055
$$

c. Koefisien korelasi reward dengan return on equity

$$
\mathrm{R}_{\mathrm{xy} 3}=1-\frac{6 \times 233.218}{140\left(140^{2}-1\right)}=0,49002
$$

Menurut Sugiyono (2007) pedoman untuk memberikan interpretasi koefisien korelasi sebagai berikut:

$$
\begin{array}{ll}
0,00-0,199 & =\text { sangat lemah } \\
0,20-0,399 & =\text { lemah } \\
0,40-0,599 & =\text { sedang } \\
0,60-0,799 & =\text { kuat } \\
0,80-1,000 & =\text { sangat kuat }
\end{array}
$$

Dari hasil olah data (output) diperoleh nilai Koefisien korelasi (R) sebesar 0,11, maka dapat disimpulkan bahwa terjadi hubungan yang masuk kategori sangat lemah antara reward dengan kinerja keuangan dengan indikator debt to equity pada perusahaan perbankan di bursa efek indonesia. Dan dilihat dari nilai koefisien determinasi $\left(\mathrm{R}^{2}\right)$ sebesar 0,0121 atau 1,21\% maka dapat dikatakan bahwa persentase sumbangan pengaruh variabel independen (reward) terhadap variabel dependen (kinerja keuangan) dengan indikator debt to equity sebesar 1,21\% sedangkan sisanya sebesar $98,79 \%$ dipengaruhi atau dijelaskan oleh faktor lain yang tidak dimasukkan dalam model ini. 
Dari hasil olah data (output) diperoleh nilai Koefisien korelasi (R) sebesar 0,442, maka dapat disimpulkan bahwa terjadi hubungan yang masuk kategori sedang antara reward dengan kinerja keuangan dengan indikator return on investment pada perusahaan perbankan di bursa efek indonesia. Kemudian dilihat dari nilai koefisien determinasi $\left(\mathrm{R}^{2}\right)$ sebesar 0,1954 atau 19,54\% maka dapat dikatakan bahwa persentase sumbangan pengaruh variabel independen (reward) terhadap variabel dependen (kinerja keuangan) dengan indikator return on investment sebesar $19,54 \%$ sedangkan sisanya sebesar $80,46 \%$ dipengaruhi atau dijelaskan oleh faktor lain yang tidak dimasukkan dalam model ini.

Dari hasil olah data (output) diperoleh nilai Koefisien korelasi (R) sebesar 0,490, maka dapat disimpulkan bahwa terjadi hubungan yang masuk kategori sedang antara reward dengan kinerja keuangan dengan indikator return on equity pada perusahaan perbankan di bursa efek indonesia. Kemudian dilihat dari nilai koefisien determinasi $\left(\mathrm{R}^{2}\right)$ sebesar 0,2401 atau 24,01\% maka dapat dikatakan bahwa persentase sumbangan pengaruh variabel independen (reward) terhadap variabel dependen (kinerja keuangan) dengan indikator return on equity sebesar $24,01 \%$ sedangkan sisanya sebesar $75,99 \%$ dipengaruhi atau dijelaskan oleh faktor lain yang tidak dimasukkan dalam model ini. Pembuktian hipotesis guna mengetahui hubungan variabel $\mathrm{X}$ dengan variabel $\mathrm{Y}$ dilakukan dengan uji koefisien parsial (uji t) dengan rumusan sebagai berikut:

$$
\mathrm{T}=\frac{\mathrm{r} n-2}{\sqrt{1-\mathrm{r}^{2}}}
$$

Berdasarkan rumus tersebut diatas diperoleh $\mathrm{t}$ hitung untuk mengetahui hubungan variabel X (reward) dengan variabel Y (kinerja keuangan dengan indikator debt to equity, return on investment, dan return on equity) adalah sebagai berikut:

a. Pengujian koefisien Rasio Reward (X) dengan Y yaitu Kinerja keuangan (debt to equity).

$$
\mathrm{t}=\frac{0,11 \sqrt{140-2}}{\sqrt{1-0,11^{2}}}=1,3001
$$

Dengan menggunakan tingkat signifikansi 0,05 karena uji dua sisi maka 2,5\% dan $\mathrm{n}=$ 140 diperoleh $\mathrm{t}$ tabel sebesar $=1,977$. Sedangkan $\mathrm{t}$ hitung dilihat dari output olah data adalah 1,3001 ( $\mathrm{t}$ hitung $<\mathrm{t}$ tabel) maka berdasarkan uji $\mathrm{t}$ ini disimpulkan reward tidak ada hubungan dengan kinerja keuangan dengan indikator debt to equity pada perusahaan perbankan di Bursa Efek Indonesia. 
Menurut Purba dan Sucipto (2009) debt to equity berguna untuk mengetahui seberapa besar aktiva perusahaan dibiayai dari utang. Dengan kata lain rasio ini untuk mengetahui setiap rupiah modal sendiri yang dijadikan untuk jaminan utang dan biasanya rasio ini dinyatakan dalam persentase. Bagi bank semakin besar rasio ini akan semakin tidak menguntungkan, karena semakin besar resiko yang ditanggung atas kegagalan yang mungkin terjadi di perusahaan, namun bagi perusahaan justru semakin besar rasio akan semakin baik. Berkenaan dengan hasil penelitian ini pemberian reward bisa saja berdampak positif pada kinerja eksekutif, namun justru eksekutif perbankan yang baik tidak akan serta-merta meningkatkan rasio debt to equity.

b. Pengujian koefisien Rasio Reward (X) dengan Y yaitu Kinerja keuangan (return on investment)

$$
\mathrm{t}=\frac{0,442 \sqrt{140-2}}{\sqrt{1-0,442^{2}}}=5,7884
$$

Dengan menggunakan tingkat signifikansi 0,05 karena uji dua sisi maka 2,5\% dan $n=$ 140 diperoleh $\mathrm{t}$ tabel sebesar $=1,977$. Sedangkan $\mathrm{t}$ hitung dilihat dari output olah data adalah 5,7884 ( $\mathrm{t}$ hitung $>\mathrm{t}$ tabel) maka berdasarkan uji $\mathrm{t}$ ini disimpulkan reward ada hubungan dengan kinerja keuangan dengan indikator return on investment pada perusahaan perbankan di Bursa Efek Indonesia. Hasil pengujian ini sesuai dengan penelitian Harvie et al. 2000, yang menemukan bahwa melalui insentif orang akan termotivasi untuk bekerja dengan baik dan memberikan kinerja yang meningkat atau baik bagi perusahaan.

c. Pengujian koefisien Rasio Reward (X) dengan Y yaitu Kinerja keuangan (return on equity)

$$
\mathrm{t}=\frac{0,490 \sqrt{140-2}}{\sqrt{1-0,490} 0^{2}}=6,63034
$$

Dengan menggunakan tingkat signifikansi 0,05 karena uji dua sisi maka 2,5\% dan $n=$ 140 diperoleh $\mathrm{t}$ tabel sebesar $=1,977$. Sedangkan $\mathrm{t}$ hitung dilihat dari output olah data adalah 6,63034 ( $\mathrm{t}$ hitung $>\mathrm{t}$ tabel) maka berdasarkan uji $\mathrm{t}$ ini disimpulkan reward ada hubungan dengan kinerja keuangan dengan indikator return on equity pada perusahaan perbankan di Bursa Efek Indonesia. Hasil pengujian ini juga sesuai dengan penelitian Harvie et al. 2000, yang menemukan bahwa melalui insentif orang akan termotivasi untuk bekerja dengan baik dan memberikan kinerja yang meningkat atau baik bagi perusahaan. 


\section{Simpulan dan Saran}

\subsection{Simpulan}

Berdasarkan hasil analisis dan pembahasan, maka dapat ditarik kesimpulan bahwa reward ada hubungan dengan kinerja keuangan dengan ROI dan ROE dengan rincian sebagai berikut:

a. Berdasarkan nilai koefisien korelasi disimpulkan bahwa terjadi hubungan yang sangat lemah antara reward dengan kinerja keuangan (debt to equity), artinya berapapun besarnya reward yang diterima eksekutif pada objek peneilitan ini tidak dapat dikaitkan dengan perubahan kinerja keuangan (debt to equity) yang terjadi. Sedangkan hubungan yang masuk kategori sedang antara reward dengan kinerja keuangan (dengan return on investment dan return on equity) pada perusahaan perbankan di Bursa Efek Indonesia, artinya semakin besar reward yang diterima oleh eksekutif pada objek penelitian ini maka akan semakin besar pula peningkatan kinerja keuangan (dengan return on investment dan return on equity).

b. Berdasarkan hasil uji hipotesis melalui uji t, maka disimpulkan bahwa tidak ada hubungan dengan debt to equity, artinya pemberian reward bisa saja berdampak positif pada kinerja eksekutif, namun justru eksekutif perbankan yang baik tidak akan sertamerta meningkatkan rasio debt to equity karena bagi perusahaan perbankan peningkatan rasio ini tidaklah menguntungkan. Sedangkan terhadap return on investment dan return on equity reward ada hubungan pada perusahaan perbankan di Bursa Efek Indonesia. Hasil pengujian ini juga sesuai dengan penelitian Harvie et al. 2000, yang menemukan bahwa melalui insentif orang akan termotivasi untuk bekerja dengan baik dan memberikan kinerja yang meningkat atau baik bagi perusahaan

c. Nilai Koefisien Determinasi $\left(\mathrm{R}^{2}\right)$ terhadap debt to equity, return on investment, dan return on equity yang sangat kecil. Hal ini menggambarkan bahwa reward dapat menjelaskan kinerja keuangan sangat kecil, dan lebih dominan dipengaruhi faktor lain yang tidak dibahas pada penelitian ini.

\subsection{Saran}

Berdasarkan hasil analisis dan kesimpulan diatas maka saran-saran yang semoga dapat menjadi masukan sebagai berikut:

a. Berdasarkan kesimpulan bahwa terjadi hubungan yang sangat lemah antara reward dengan kinerja keuangan (dengan indikator debt to equity), dan hubungan yang sedang antara reward dengan kinerja keuangan (dengan indikator return on investment dan 
return on equity), maka perusahaan perbankan hendaknya mengevaluasi efektifitas pemberian reward yang telah dilakukan dengan kinerja keuangan perusahaan.

b. Dari hasil uji hipotesis melalui uji t, yang menyimpulkan bahwa reward hanya ada hubungan dengan kinerja keuangan dengan indikator return on investment dan return on equity, maka perusahaan hendaknya juga mengevaluasi efektifitas dan sistem pemberian reward yang telah dilakukan dengan kinerja keuangan perusahaan.

c. Dari hasil penelitian yang menemukan R-square (koefisien determinasi) angka yang sangat kecil (dibawah 25\%) untuk ketiga indikator, untuk itu penelitian ini masih perlu dilanjutkan guna mencari tahu dan membuktikan keberadaan faktor lain tersebut.

\section{Daftar Pustaka}

Afriyeni, Endang. 2008. Penilaian Kinerja Keunangan dengan Menggunakan Analisis Rasio. Jurnal Ekonomi dan Bisnis Oktober 2008 Vol.3 No.2

Agnes, Sawir. 2003 Analisis Kinerja Keuangan dan Perencanaan Keuangan . Jakarta: PT. Gramedia Utama.

Alex, S, Nitisemito, 2003, Manajemen Personalia, Penerbit Ghalia Indonesia.

Anthony, Robert N and Vijay Govindarajan, 2001, "Management Control System", $10^{\text {th }}$ Edition

Bambang Riyanto. 2001. Dasar-dasar Pembelanjaan Perusahaan, Edisi Keempat. BPFE. Penerbit UGM, Yogyakarta.

Darsono dan Ashari. 2005. Pedoman Praktis Memahami Laporan Keuangan, Ed. 1, Yogyakarta: Andi.

Dessler, Gary. 2005. Manajemen Sumber Daya Manusia. Alih bahasa: Eli Tanya. Penyunting Bahasa: Budi Supriyanto. Jakarta: Indeks.

Djarwanto, PS, Maret 2001, "Pokok-Pokok Analisa Laporan Keuangan", BPFE Yoyakarta.

Fahmi, Irham. 2011. Analisis Kinerja Keuangan, Panduan bagi Akademisi, Manajer, dan Investor untuk Menilai dan Menganalisis Bisnis dari Aspek Keuangan. Alfabeta, Bandung.

Handoko, Hani, T.2005. Manajemen Personalia dan Sumber Daya Manusia Edisi II. Badan Penerbit Fakultas Ekonomi. Yogyakarta.

Harahap, Sofyan Syafri. 2006. Analisis Kritis atas Laporan Keuangan. Jakarta: PT Raja Grafindo Persada.

Hasibuan, M. 2002. Manajemen Sumber Daya Manusia. Jakarta: CV. Haji Masagung.

Husnan, Suad, 2004, Manajemen Keuangan - Teori dan Penerapan, Buku 2, BPFE Yogyakarta.

Jaya, Wihana K.\&Nurwanto C.N, 1998, Analisis Struktur dan Kinerja Industri Bank Swasta Nasional di Indonesia Tahun 1996, Jurnal Ekonomi dan Bisnis Indonesia, Vol.13, No.1, pp.42-52. 
Mangkunegara,Achmad Anwar Prabu. 2002. Perilaku dan Budaya Organisasi.

Bandung: Aditama.

Mawardi, Wisnu, 2005, Analisis Faktor Faktor yang Mempengaruhi Kinerja Keuangan Bank Umum di Indonesia (Studi Kasus pada Bank Umum dengan Total Asset Kurang dari 1 Triliun), Jurnal Bisnis Strategi, Vol.14, No.1, Juli, p.83-94.

Mathis, R dan Jackson, W. 2006. Manajemen Sumber Daya Manusia. Jakarta: Salemba Empat

Mulyadi \& Johny Setyawan, 2001 "Sistem Perencanaan dan Pengendalian Manajemen" Universitas Dadjah Mada. h. 213-214.

Mulyono. 1999. Analisis Kegunaan Rasio Keuangan. Yogyakarta, Liberty.

Munawir. S. 2010. Analisis Laporan Keuangan. Edisi ke 4. Yogyakarta, Libert】

Nawawi, H. 2001. Manajemen Sumber Daya Manusia. Yogyakarta: Gadjah Mada University Press.

Orville C. Walker, Boyd. Harper W, Larreche, Jean Claude. 2004. Manajemen Pemasaran Suatu Pendekatan Strategis dengan Orientasi Global. Jakarta: Erlangga.

Panggabean, Mutiara S. 2002. Manajemen Sumber Daya Manusia. Jakarta: Ghalia Indonesia.

Pangaribuan, Farida., Idhar Yahya. 2009. Analisis Laporan Keuangan sebagai Dasar dalam

Penilaian Kinerja Keuangan pada PT Pelabuhan Indonesia I Medan. Jurnal Akuntansi

Universitas Sumatra Utara.

Pohan, Aulia, 2002, "Arah dan Perkembangan Kebijakan Perbankan Nasional", Ventura, Vol.5, No.1, April, pp.1-13.

Prayitno, Duwi, 2010. Paham Analisa Statistik Data Dengan SPSS, MediaKom

Purba, Mansurya Tenno., Sucipto. 2009. Analisis Rasio Keuangan sebagai Pengambilan Keputusan pada PT Intraco Penta Tbk. Medan. Jurnal Akuntansi Universitas Sumut

Ravianto. 2000. Manajemen Personalia dan Sumber Daya Manusia. Yogyakarta:BPFE.

Robbins, Stephen. P. dan Mary Coulter. 2005. Manajemen. PT INDEKS

Kelompok Gramedia. Jakarta.

Sarwoto. (2010). Dasar- Dasar Organisasi dan Manajemen, cetakan keenambelas. Jakarta : Ghalia Indonesia.

Sastrohadiwiryo, Bejo Siswanto. 2003. Manajemen Tenaga Kerja Indonesia Pendekatan Administrative dan Operasional. Jakarta: Bumi Aksara.

Simamora, Henry.2001. Manajemen Sumberdaya Manusia. STIE YKPN, Yogyakarta.

Sugiono. 2008. Statika Untuk penelitian. Bandung: Alfhabeta.

Syofyan, Sofriza, 2003, Pengaruh Struktur Pasar Terhadap Kinerja Perbankan di Indonesia, Media Riset Bisnis dan Manajemen, Vol.2, No.3, Desember, pp.194-219.

Stanton, William J., Walker, Bruce J., Etzel, Michael J. (2004). Marketing Concepts \& Cases. 13th edition, New York: McGraw-Hill.

Susetyo Budi, 2010. Statistika Untuk Analisis Data Penelitian. Refika Aditama, Bandung. 